\title{
Spatial and seasonal variability of Acartia (Copepoda) in a tropical coastal lagoon of the southern Gulf of Mexico
}

\author{
Variabilidad espacial y estacional de Acartia (Copepoda) en \\ una laguna costera del sur del Golfo de México
}

\section{Benigno J. Escamilla ${ }^{1}$, Uriel Ordóñez-López ${ }^{2}$ and Eduardo Suárez-Morales ${ }^{3}$}

${ }^{1}$ Instituto Tecnológico de Mérida, Av. Tecnológico s/n, Mérida, Yucatán 97118, México

${ }^{2}$ Centro de Investigación y de Estudios Avanzados (CINVESTAV), Unidad Mérida, Km 6 carretera a Progreso, A.P. 73, Mérida, Yucatán 97310, México

${ }^{3}$ El Colegio de la Frontera Sur (ECOSUR), Av. Centenario Km 5.5, Chetumal, Quintana Roo 77014, México. esuarez@ecosur.mx

Resumen.- En este estudio se analizó la variabilidad estacional de la distribución y abundancia de especies de copépodos del género Acartia en una laguna costera de la costa norte de la Península de Yucatán, México, durante meses representativos de las tres épocas climáticas (secas, lluvias y nortes) de un ciclo anual. Se caracterizaron dos áreas distintas (interna y externa) de la laguna, basadas en su salinidad y biomasa de copépodos. Acartia lilljeborgii y $A$. tonsa fueron las especies más abundantes, y juntas representaron cerca del 95,5\% del número total del género; la fracción remanente estuvo representada por A. spinata. Más de la mitad (52.3\%) de la abundancia total de $A$. tonsa ocurrió en la época de lluvias, $30.6 \%$ durante nortes y $17.1 \%$ en la época seca. Los valores estacionales correspondientes de $A$. lilljeborgii fueron $57 \%$ en secas, $21.3 \%$ en lluvias y $20.4 \%$ en nortes. El $85 \%$ de los individuos de $A$. spinata ocurrieron en nortes. En épocas secas sólo $A$. tonsa fue más abundante en la zona interna mientras que $A$. lilljeborgii dominó la zona externa en la misma época. El análisis de correlación reveló cambios estacionales en la manera en que las especies de Acartia se relacionan con diferentes factores bióticos y abióticos. Acartia tonsa y A. spinata mostraron diferencias significativas relacionadas con la época y esta última a la combinación de zona (interna-externa) y la época. La variación espacial y temporal de la abundancia de las especies de Acartia estuvo relacionada con las condiciones hidro-biológicas de la laguna de cada estación. Por lo tanto, los cambios locales y de pequeña escala, y la respuesta de las especies según las condiciones estacionales, favorecen la coexistencia de los copépodos en este sistema lagunar.

Palabras clave: Zooplancton costero, ecología del plancton, copépodos, abundancia estacional, Atlántico Tropical Noroccidental

\begin{abstract}
In this study, the seasonal variability of the distribution and abundance of the copepod Acartia spp. in a coastal lagoon on the northern coast of the Yucatan Peninsula, Mexico, was analyzed during representative months of the three main seasons (dry, rainy, and northerlies=nortes) of an annual cycle. Also, two distinct areas of the lagoon (inner and outer) were revealed according to salinities and zooplankton biomass. Acartia lilljeborgii and $A$. tonsa were the most abundant species, representing together up to $95.5 \%$ of the overall abundance of the genus. More than half $(52.3 \%)$ of the total abundance of $A$. tonsa occurred in the rainy season, $30.6 \%$ during nortes, and $17.1 \%$ in the dry season. Corresponding seasonal values for A. lilljeborgii were $57 \%$ in the dry season, $21.3 \%$ in the rainy season, and 20.4 in nortes. Up to $85 \%$ of the individuals of $A$. spinata occurred during nortes. Only in the dry season $A$. tonsa was most abundant species at the inner zone, whereas A. lilljeborgii was dominant in the outer zone during the same season. The correlation analysis revealed seasonal changes in the way that species of Acartia relate to different biotic and abiotic factors: Acartia tonsa and A. spinata showed significant differences related to the season and the former species to the combination of zone (inner-outer) and season. The spatial and temporal variation of Acartia species abundance was related to seasonal changes of the hydro-biological conditions of the lagoon. Hence, the local and small scale changes, together with the seasonal conditions and the response of these species to them, favor their coexistence in this lagoon system.
\end{abstract}

Key words: Coastal zooplankton, plankton ecology, copepods, seasonal abundance, Northwestern Tropical Atlantic 


\section{INTRODUCTION}

The aquatic biota of coastal systems such as lagoons, estuaries, and bays is affected by continuous, cyclical changes of environmental conditions both temporally and spatially as a result of the influence of tides, coastal currents, freshwater runoff, atmospheric processes, and human activities (Elliott \& McLusky 2002). The zooplankton community is also affected by the variability of physical and chemical parameters and by the nutrient input from adjacent ecosystems (Malone et al. 1996, Waniek 2003).

Copepods compose the most relevant groups of coastal zooplankton; they usually represent 60 to $95 \%$ of the total biomass in coastal lagoons (Suárez-Morales 1994b, Lopes et al. 1998). Species of the genus Acartia are consistently present in these environments. Acartia tonsa Dana, 1852, A. lilljeborgii Giesbrecht, 1889, and $A$. spinata Esterly, 1911 have been previously reported as abundant and common in different coastal systems of the Northwestern Tropical Atlantic (Suárez-Morales 1994a, Suárez-Morales \& Gasca 1996, Álvarez-Cadena \& Segura-Puertas 1997, Escamilla \& Suárez-Morales 1999, Escamilla et al. 2001, Ordóñez-López \& Ornelas-Roa 2003, Álvarez-Cadena et al. 2007).

Distributional patterns of lagoonal planktonic copepods are influenced by environmental factors (Hwang et al. 2006). Salinity gradients resulting from varying intensities of marine influence and freshwater runoff often represent the main parameter in defining the local distributional patterns and succession of species of Acartia (Suárez-Morales 1994a). In some tropical estuarine systems seasonal variations have been described as weak despite the variability of hydrographic conditions and in other cases seasonal changes do not correspond to the expected pattern based on their known ecological affinities (Hwang et al. 2010). Therefore, in order to understand the dynamics of the planktonic biota, the study of the distribution and abundance of copepods and its variability represents a basic step. In this study we analyzed the seasonal abundance and distributional patterns of copepods of the genus Acartia in relation to the variation of zooplankton biomass and physical and chemical parameters in a coastal lagoon of the southern Gulf of Mexico.

Chelem lagoon is a coastal karstic shallow system partially protected by a sand barrier; it is located on the northern coast of the Yucatan Peninsula, Mexico $\left(21^{\circ} 17^{\prime} \mathrm{N}\right.$; $89^{\circ} 40^{\prime} \mathrm{W}$ ). The lagoon is approximately $25 \mathrm{~km}$ long, $800 \mathrm{~m}$ wide, and it has an average depth of $1.3 \mathrm{~m}$; it has a northsouth and east-west slope causing a weak runoff to the north and west (Zizumbo 1989). Since 1968 it has a permanent connection to the sea; it is influenced by waters from the Gulf of Mexico and the Caribbean Sea and during the dry season it becomes hyper-saline, but in some conditions it can become oligohaline (ValdésLozano 1995, Herrera-Silveira et al. 1999, Herrera-Silveira 2006). The inner flows of water in the lagoon are influenced mainly by tidal currents; tides in Chelem are mixed semidiurnal.

\section{Materials ANd Methods}

Zooplankton samples were collected in February, June, and October, 2000 by performing surface tows at eight sampling stations (Fig. 1). These months were selected as the most representative of the three main seasons that characterize the climate in this region: northerlies or nortes (February), dry (June), and rainy (October). A conical net of $30 \mathrm{~cm}$ mouth diameter, $120 \mathrm{~cm}$ long, and $0.33 \mathrm{~mm}$ mesh size was used in all cases (Harris et al. 2000). A General Oceanics 2030 digital flowmeter was adapted to the net mouth in order to estimate the amount of water filtered by the net. Sampling was conducted during the day between 08:00 and 14:00 $\mathrm{h}$ by trawling the net for $5 \mathrm{~min}$. The biological material was fixed in a $4 \%$ formalin solution in seawater buffered with sodium borate.

Hydrological parameters including temperature $( \pm$ $\left.0.5^{\circ} \mathrm{C}\right)$, salinity $( \pm 0.1)$, and dissolved oxygen were measured at each sampling site with the aid of a YSI8550FT field multisensor; $\mathrm{pH}$ values were obtained with a Corning field potentiometer. All measurements were obtained at mid-water depth. Zooplankton biomass was obtained by the method of wet weight $\left(\mathrm{mg} \mathrm{m}^{-3}\right.$ ) (Beers 1981) using an Ohaus analytical scale $( \pm 0.1 \mathrm{mg})$. The species of Acartia were identified following CamposHernández \& Suárez-Morales (1994). The numerical abundance of copepods was standardized to organisms $100 \mathrm{~m}^{-3}$. Hydrographic data (depth, temperature, salinity, $\mathrm{pH})$ were analyzed by the Ward Agglomerative Method with Euclidean distances linkage in order to identify affinities among groups of stations and then processed by a one-way ANOVA $(P<0.05$, Zar 1988$)$ to detect differences related to a single variable. A two-way ANOVA was performed with both the biotic and abiotic data to evaluate the space and time variability. Using the abundance data of the species of Acartia we performed a canonical correspondence analysis (CCA) (CONOCO 4.5) with $\log +1$-transformed data to determine the relationships 
Figure 1. Location of the surveyed area and zooplankton sampling sites in Chelem lagoon system, Yucatan Peninsula, Mexico / Localización del área de estudio y de los sitios de muestreo de zooplancton en la laguna de Chelem, Península de Yucatán, México

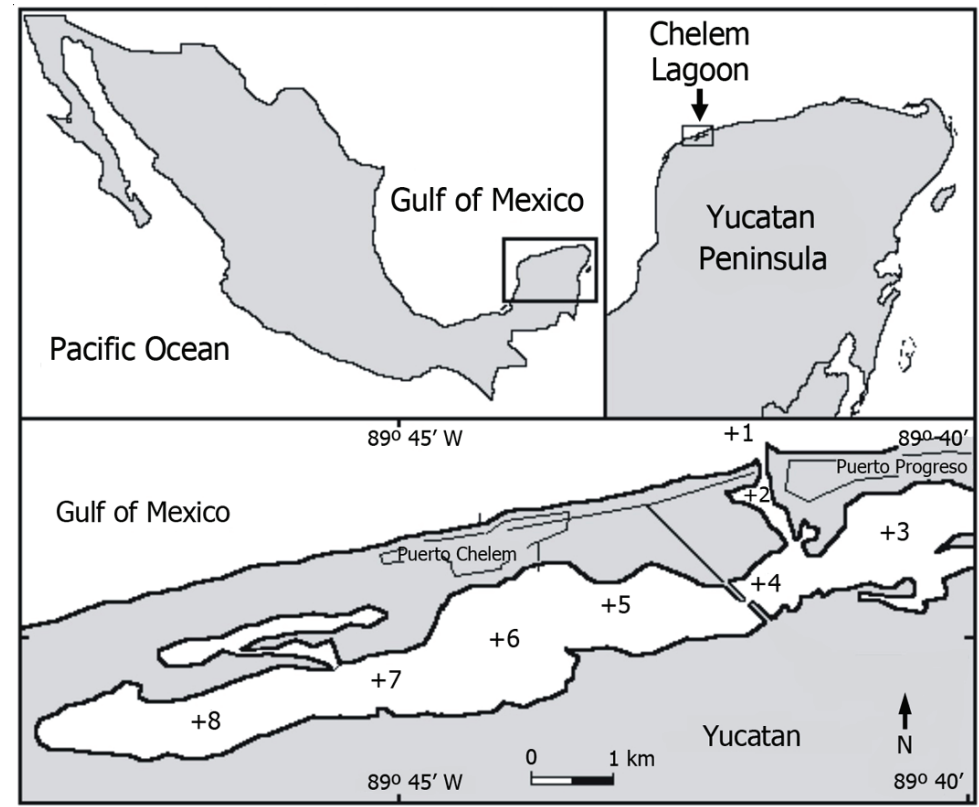

between copepod species and the parameters recorded during each of the three seasonal periods included in this survey (Braak \& Verdonschot 1995).

\section{Results}

\section{Hydrological features}

The cluster analysis of the sampling stations, based on the average values of the main environmental variables measured, allowed the detection of two distinctive areas, each containing four sampling stations: internal (sta. 1-4) and external (sta. 5-8). Each zone was significantly different $(P>0.05)$ with respect to the other in terms of the physical and chemical variables evaluated (Fig. 2, Table 1).

The average depth was $2.1 \pm 1.1 \mathrm{~m}$ for the outer and 0.8 $\pm 0.01 \mathrm{~m}$ for the inner sector. The lowest average was recorded during the nortes season within the inner zone; the highest average was observed in the outer zone during the rainy season (Table 1).

The overall average temperature for the inner sector $\left(25.9^{\circ} \mathrm{C}\right)$ was $1.2^{\circ} \mathrm{C}$ higher than in the outer sector. The highest seasonal value was recorded during the dry season $\left(28.1 \pm 1.2^{\circ} \mathrm{C}\right)$, whereas the lowest occurred during nortes $\left(21.0 \pm 0.8^{\circ} \mathrm{C}\right)$.

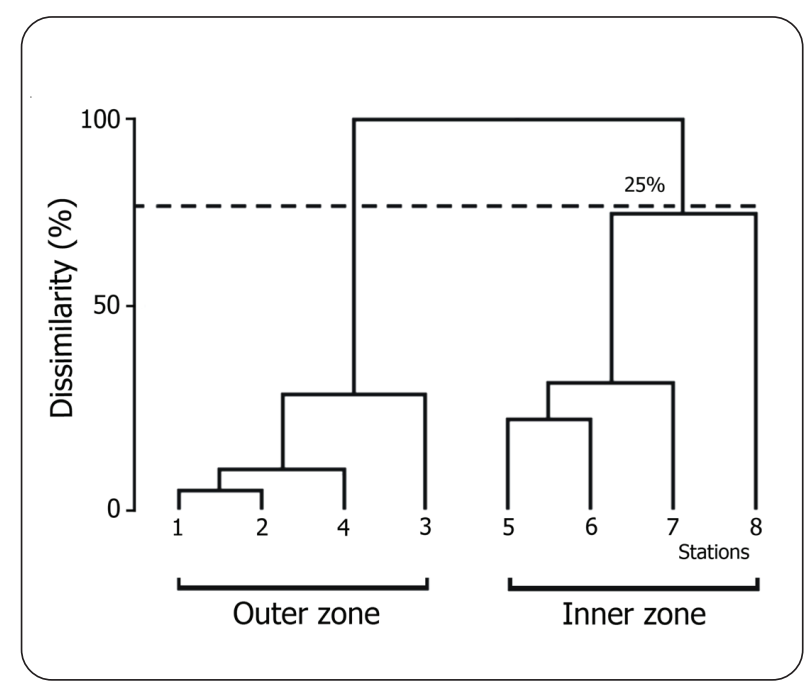

Figure 2. Dendrogram showing hydrographic affinities of sampling stations in Chelem lagoon dividing the system into two distinct zones (inner and outer). Data were $\log _{10}$ transformed before comparing stations by using the Bray-Curtis index / Dendrograma que muestra las afinidades hidrográficas entre las estaciones de muestreo en la laguna de Chelem dividiendo el sistema en dos zonas distintas (interna y externa). Datos transformados $\left(\log _{10}\right)$ antes de comparar las estaciones mediante el Indice de Bray-Curtis 
Table 1. Spatial (inner/outer hydrographic zones) and seasonal (nortes, dry, rainy) variation of the hydro-biological parameters evaluated in Chelem lagoon, Mexico during the surveyed period. Std: Standard deviation / Variación espacial (zonas interna/externa) y estacional (nortes, secas, lluvias) de los parámetros hidro-biológicos evaluados en la laguna de Chelem, México durante el periodo estudiado. Std: Desviación estándar

\begin{tabular}{|c|c|c|c|c|c|c|c|}
\hline \multirow{2}{*}{$\frac{\text { Season }}{\text { Variable / Zone }}$} & \multicolumn{2}{|c|}{ Nortes } & \multicolumn{2}{|c|}{ Dry } & \multicolumn{2}{|c|}{ Rainy } & \multirow[b]{2}{*}{ Average } \\
\hline & Inner & Outer & Inner & Outer & Inner & Outer & \\
\hline \multicolumn{8}{|l|}{ Abiotic } \\
\hline Depth (m) & 0.80 & 1.87 & 0.84 & 2.42 & 0.89 & 2.29 & 1.33 \\
\hline (Std) & 0.14 & 0.97 & 0.05 & 1.36 & 0.09 & 2.29 & 0.87 \\
\hline Temperature $\left({ }^{\circ} \mathrm{C}\right)$ & 21.42 & 20.92 & 28.96 & 27.46 & 27.92 & 26.21 & 25.48 \\
\hline (Std) & 0.90 & 0.90 & 0.96 & 0.89 & 0.51 & 0.26 & 3.27 \\
\hline Salinity (psu) & 25.17 & 32.21 & 28.29 & 31.21 & 24.16 & 28.13 & 28.19 \\
\hline (Std) & 2.87 & 2.62 & 0.26 & 2.62 & 1.96 & 2.52 & 3.68 \\
\hline Oxygen $\left(\mathrm{mg} \mathrm{l}^{-1}\right)$ & 8.09 & 6.72 & 6.56 & 6.39 & 7.31 & 5.86 & 6.82 \\
\hline (Std) & 0.40 & 0.57 & 2.13 & 0.32 & 1.07 & 0.61 & 1.24 \\
\hline $\mathrm{pH}$ & 8.40 & 8.00 & 8.41 & 8.14 & 8.48 & 8.34 & 8.29 \\
\hline (Std) & 0.10 & 0.12 & 0.10 & 0.03 & 0.05 & 0.11 & 0.19 \\
\hline \multicolumn{8}{|l|}{ Biotic } \\
\hline Biomass ( $\mathrm{mg} \mathrm{m}^{-3}$ ) & 134.8 & 137.5 & 106.7 & 425.4 & 62.4 & 51.1 & 114.7 \\
\hline$(\mathrm{Std})$ & 26.3 & 29.8 & 26.5 & 88.5 & 9.2 & 7.9 & 92.9 \\
\hline $\begin{array}{l}\text { Zooplankton Density } \\
\text { (org. } 100 \mathrm{~m}^{-3} \text { ) }\end{array}$ & 168037.0 & 99934.0 & 77587.0 & 443348.0 & 77587.0 & 117877.0 & 123046.3 \\
\hline (Std) & 36734.5 & 11886.6 & 6330.1 & 153491.7 & 6330.1 & 25646.1 & 112996.2 \\
\hline $\begin{array}{l}\text { Copepod density } \\
\text { (Copep. } 100 \mathrm{~m}^{-3} \text { ) } \\
\text { (Std) }\end{array}$ & 37125.0 & 55766.0 & 30741.0 & 50928.0 & 35024.0 & 72085.0 & $\begin{array}{l}35208.6 \\
182820\end{array}$ \\
\hline$(\mathrm{Std})$ & 7046.0 & 11162.9 & 4122.2 & 9677.0 & 3507.0 & 17291.2 & 18282.0 \\
\hline
\end{tabular}

Table 2. Values of $F$ and $P$ from the two-way ANOVA of the biotic and abiotic factors (log +1 transformed data) in Chelem during the surveyed period. Significant values in boldface / Valores de F y $P$ obtenidos del ANDEVA de dos vías de los factores bióticos y abióticos (datos transformados a log+1) en Chelem durante el periodo estudiado. Valores significativos en negritas

\begin{tabular}{|c|c|c|c|c|c|c|c|c|c|}
\hline & \multicolumn{9}{|c|}{ Effects } \\
\hline & \multicolumn{3}{|c|}{ Zone (2) } & \multicolumn{3}{|c|}{ Season (3) } & \multicolumn{3}{|c|}{ Zone x Season } \\
\hline & $\mathrm{F}$ & g.l. & $P$ & $\mathrm{~F}$ & g.l. & $P$ & $\mathrm{~F}$ & g.l. & $P$ \\
\hline \multicolumn{10}{|l|}{ Abiotic } \\
\hline Depth & 41.25 & 1 & $<0.001$ & 0.78 & 2 & 0.464 & 0.18 & 5 & 0.839 \\
\hline Temperature & 43.46 & 1 & $<0.001$ & 567.34 & 2 & $<0.001$ & 3.69 & 5 & 0.030 \\
\hline Salinity & 67.30 & 1 & $<0.001$ & 14.59 & 2 & $<0.001$ & 4.85 & 5 & 0.010 \\
\hline Oxygen & 11.91 & 1 & $<0.001$ & 6.59 & 2 & $<0.001$ & 3.91 & 5 & 0.024 \\
\hline $\mathrm{pH}$ & 96.81 & 1 & $<0.001$ & 27.92 & 2 & $<0.001$ & 8.46 & 5 & $<0.001$ \\
\hline \multicolumn{10}{|l|}{ Biotic } \\
\hline Biomass & 1.13 & 1 & 0.302 & 2.73 & 2 & 0.092 & 1.17 & 5 & 0.332 \\
\hline Zooplankton density & 1.10 & 1 & 0.308 & 0.67 & 2 & 0.522 & 2.03 & 5 & 0.160 \\
\hline Copepod density & 1.91 & 1 & 0.183 & 0.24 & 2 & 0.787 & 0.01 & 5 & 0.990 \\
\hline
\end{tabular}


Salinity showed a higher overall average in the outer sector of the lagoon $(28.1 \pm 1.0 \mathrm{psu})$; salinity was lower (25.8 psu) within the inner sector. The highest salinity average occurred during the dry period $(28.3 \pm 0.8 \mathrm{psu})$ and the lowest in the rainy season $(24.1 \pm 2.3 \mathrm{psu})$. Dissolved oxygen showed the highest average value during the northerlies season $\left(8.0 \pm 2.3 \mathrm{mg} \mathrm{L}^{-1}\right)$, lower values were observed both in dry and wet seasons (see Table 1).

Overall, recorded $\mathrm{pH}$ values were slightly alkaline in the lagoon; the highest average was observed for the inner sector $(8.5 \pm 0.08), 0.3$ units higher than in the outer area; the highest seasonal average was recorded in the rainy season $(8.48 \pm 0.1)$ (Table 1$)$. The two-way ANOVA of the hydrological data confirmed these zonal differences (Table 2).

\section{BIOMASS, ZOOPLANKTON AND COPEPOD ABUNDANCE}

Overall, the average zooplankton biomass of the surveyed lagoon was $114.7 \pm 92.9 \mathrm{mg} \mathrm{m}^{-3}$. Considering the two main hydrologic areas defined, the average zooplankton biomass recorded in the outer sector during the year cycle was $204.5 \pm 61.6 \mathrm{mg} \mathrm{m}^{-3}$, almost two times higher than the inner sector $\left(103.5 \pm 20.6 \mathrm{mg} \mathrm{m}^{-3}\right)$. During the dry season, this biomass value was highly variable (see Table 1); the average $\left(265.5 \pm 92 \mathrm{mg} \mathrm{m}^{-3}\right)$ was almost twice that recorded during nortes $\left(136 \pm 21.4 \mathrm{mg} \mathrm{m}^{-3}\right)$ and up to 4.5 times of that observed in the rainy season $\left(56.7 \pm 8.3 \mathrm{mg} \mathrm{m}^{-3}\right)$. The total zooplankton abundance average was $123,046 \pm$ 112,996 org. $100 \mathrm{~m}^{-3}$ (see Table 1). Highest averages were recorded during the dry season in the outer sector, about two times higher than that for the inner zone. During this period zooplankton abundance was between 1.9 and 2.5 times higher than in northerlies and the rainy seasons, respectively (Table 1). The total average abundance of copepods followed a different pattern where highest values were recorded during the rainy season for the outer sector $\left(72,085 \pm 17,291 \mathrm{org} .100 \mathrm{~m}^{-3}\right)$, about twice the figure recorded from the internal part of the lagoon in the same season. During the other two seasons, copepod abundance values were lower but the same pattern prevailed, with higher values shown for the outer zone (Table 1).

\section{Abundance And distribution of A Cartia}

Copepods represented up to $55 \%$ of the total numerical abundance of the zooplankton in the surveyed area. Species of Acartia represented more than $84 \%$ of the local copepod fauna. Three species of this genus were present in our samples: A. lilljeborgii, accounting for $49.8 \%$ of the total number of acartiids, followed by $A$. tonsa (45.6\%), and $A$. spinata (4.6\%). The seasonal relative abundance of $A$. tonsa was variable; $52.3 \%$ of the total number of this species occurred during the rainy season, $30.6 \%$ in the nortes, and $17.1 \%$ in the dry season. The seasonal values of $A$. lilljeborgii were $57.0 \%$ in the dry season, $21.8 \%$ in the rainy season, and $20.4 \%$ during the nortes. Acartia spinata was the less abundant and less frequent, up to $85.6 \%$ of its abundance was observed during northerlies, $13.6 \%$ in the rainy season, and $0.8 \%$ during the dry season (Table 3).

Table 3. Spatial (inner/outer hydrographic zones) and seasonal (nortes, dry, rainy) variation of the total numerical abundance (org. $100 \mathrm{~m}^{-3}$ ) for species of Acartia in Chelem lagoon, Mexico during the surveyed period. Std: Standard deviation / Variación espacial (zonas interna/externa) y estacional (nortes, secas, lluvias) de las abundancias totales (org. $100 \mathrm{~m}^{-3}$ ) de las especies de Acartia en la laguna de Chelem, México durante el periodo estudiado. Std: Desviación estándar

\begin{tabular}{crrrrrrrr}
\hline \multirow{2}{*}{ Season } & \multicolumn{2}{c}{ Nortes } & \multicolumn{2}{c}{ Dry } & \multicolumn{2}{c}{ Rainy } & \multicolumn{2}{c}{ Total } \\
\hline Species / Zone & \multicolumn{1}{c}{ Inner } & \multicolumn{1}{c}{ Outer } & \multicolumn{1}{c}{ Inner } & Outer & Inner & Outer & Inner & Outer \\
\hline A. tonsa & 7420.0 & 18721.0 & 11422.0 & 3208.0 & 18388.0 & 26334.0 & 37230.0 & 48263.0 \\
$\quad($ Std) & 1537.6 & 3206.0 & 1534.3 & 572.1 & 2689.4 & 5258.0 & 5550.3 & 11785.7 \\
A. lilljeborgii & 12630.0 & 6373.0 & 17809.0 & 36190.0 & 7806.0 & 12488.0 & 38245.0 & 55051.0 \\
$\quad$ (Std) & 2917.8 & 2323.1 & 3361.0 & 7693.9 & 628.5 & 1831.3 & 5002.5 & 15749.2 \\
A. spinata & 1302.0 & 6035.0 & 13.0 & 47.0 & 632.0 & 586.0 & 1947.0 & 6668.0 \\
$\quad($ Std) & 325.7 & 1485.0 & 6.5 & 9.4 & 164.3 & 174.0 & 644.7 & 3312.6 \\
Total & 21352.0 & 31129.0 & 29244.0 & 39445.0 & 26826.0 & 39408.0 & 77422.0 & 109982.0 \\
$\quad$ (Std) & 5670.1 & 7228.7 & 9015.3 & 20017.2 & 8932.3 & 12886.2 & 4043.4 & 4790.6 \\
\hline
\end{tabular}


The highest mean abundances of Acartia were recorded for the outer zone of the lagoon system, up to $58.7 \%$ of the individuals occurred in this sector (Table 3 ). Acartia tonsa and A. lilljeborgii were, in general, more abundant in the outer sector than within the inner zone, but $A$. spinata showed an opposite pattern, it was about four times more abundant in the outer sector (Table 3). These patterns showed seasonal variations; $A$. tonsa was more abundant in the outer zone during the nortes and rainy periods but a reverse pattern occurred in the dry season, when its abundance was three-fold higher within the inner zone (see Table 2). In the same season (dry), $A$. lilljeborgii showed the opposite tendency, it was twice as abundant in the outer zone (Table 3); it was also more abundant in the outer zone during the rainy season. Acartia spinata was clearly more abundant in the outer zone except for the rainy season, during which it was equally abundant in both areas of the lagoon (Table 3 ).

In terms of seasonal variation, $A$. tonsa was mostly abundant in the rainy season, followed by nortes and the dry season. Acartia lilljeborgii had its highest abundance during the dry period, which was between 2.5 and 3 times higher than in the rainy and northerlies periods, respectively. Acartia spinata, though relatively scarce, showed its highest abundance during nortes, clearly higher than that in the other two seasonal periods (see Table 3). Significant differences in the abundances of $A$. tonsa and A. spinata were found among seasons (Table 4).

\section{ENVIRONMENTAL PARAMETERS AND ACARTIA}

The canonical correlation analysis (CCA) between measured environmental variables and the abundance of species of Acartia in the surveyed area, yielded values over $85 \%$ of the variance explained by relating component one and two during the three seasons, thus indicating a high correlation between both components. During the nortes season the variance explained was $99 \%$, axis $1=$ 85.9 , axis $2=13.1 \%$. The relation of $A$. spinata with deeper and more saline sites can be clearly observed, but the graphic also reflects the high density of $A$. tonsa in the same conditions, particularly in the outer zone of Chelem, where it had its highest densities. Acartia lilljeborgii was associated with relatively warmer water and with higher $\mathrm{pH}$ values and oxygen. Biomass was more correlated with depth than with salinity (Fig. 3). During

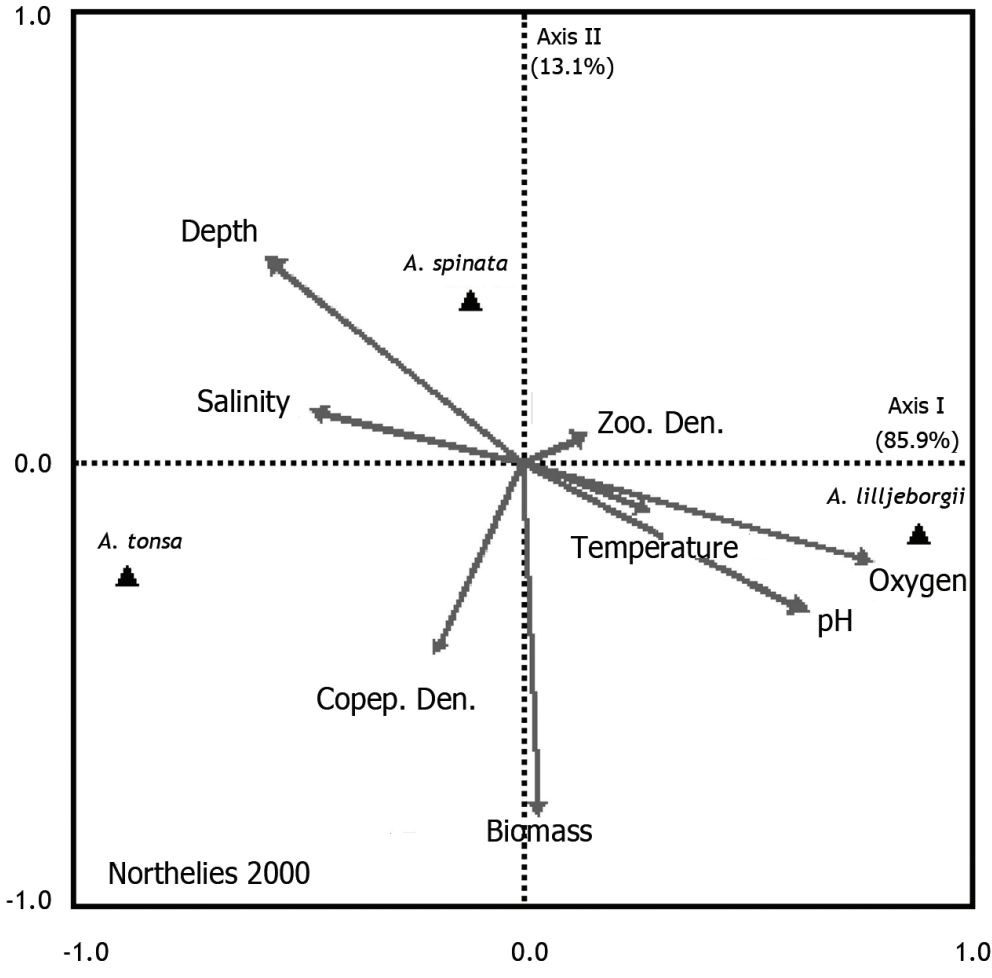

Figure 3. Canonical Correspondence Analysis (CCA) of hydrographic and biological data for species of Acartia during the nortes season. Data were $\log _{10}$ transformed / Análisis de Correspondencia Canónica (CCA) de los datos hidrográficos y biológicos con respecto a las especies de Acartia durante la época de nortes. Datos transformados $\left(\log _{10}\right)$ 
the dry season the variance explained was 99\% (axis $1=$ $92 \%$, axis $2=7.0 \%$ ), A. tonsa showed low correlation with most variables but a high correlation with $\mathrm{pH}$ values and temperature; the position of $A$. spinata, close to the axes origin $(0,0)$, suggests an overall low correlation with the parameters measured during this season. Acartia lilljeborgii was associated with relatively higher values of oxygen and biomass and low values of $\mathrm{pH}$ and temperature (Fig. 4). Finally, during the rainy period, the variance explained was $99 \%$ (axis $1=98.4 \%$, axis $2=0.6 \%$ ).
Both A. tonsa and A. lilljeborgii were correlated with high values of zooplankton biomass, temperature, zooplankton density, $\mathrm{pH}$, and dissolved oxygen, whereas A. spinata was related to the deeper and more saline sites, as observed during nortes (Fig. 5). Acartia tonsa and $A$. spinata showed significant differences when related to the season and the former species to the combination of zone (inner-outer) and season. The results of the ANOVA for the abundance of Acartia species in the surveyed area is presented in Table 4.

Table 4. Results of two-way ANOVAs to compare the abundance of species of Acartia (log+1transformed data) in Chelem according to zone and season during the surveyed period. Significant values in boldface / Resultados de ANDEVAs de dos vías que comparan la abundancia de las especies de Acartia (datos transformados a log+1) en Chelem según zona y estación durante el periodo estudiado. Valores significativos en negritas

\begin{tabular}{lcccccccccc}
\hline & \multicolumn{1}{c}{ Zone (2) } & \multicolumn{4}{c}{$\begin{array}{c}\text { Effects } \\
\text { Season (3) }\end{array}$} & \multicolumn{3}{c}{ Zone x Season } \\
\hline Species & F & g.l. & $P$ & F & g.l. & $P$ & F & g.l. & $P$ \\
A. tonsa & 0.05 & 1 & 0.831 & 3.89 & 2 & $\mathbf{0 . 0 3 9}$ & 3.86 & 5 & $\mathbf{0 . 0 4 0}$ \\
A. lilljeborgii & 0.63 & 1 & 0.871 & 3.04 & 2 & 0.072 & 1.50 & 5 & 0.249 \\
A. spinata & 2.72 & 1 & 0.116 & 9.54 & 2 & $\mathbf{0 . 0 0 1}$ & 0.95 & 5 & 0.405 \\
\hline
\end{tabular}

Figure 4. Canonical Correspondence Analysis (CCA) of hydrographic and biological data for species of Acartia during the dry season. Data were $\log _{10}$ transformed / Análisis de Correspondencia Canónica (CCA) de los datos hidrográficos y biológicos con respecto a las especies de Acartia durante la época de secas. Datos transformados $\left(\log _{10}\right)$

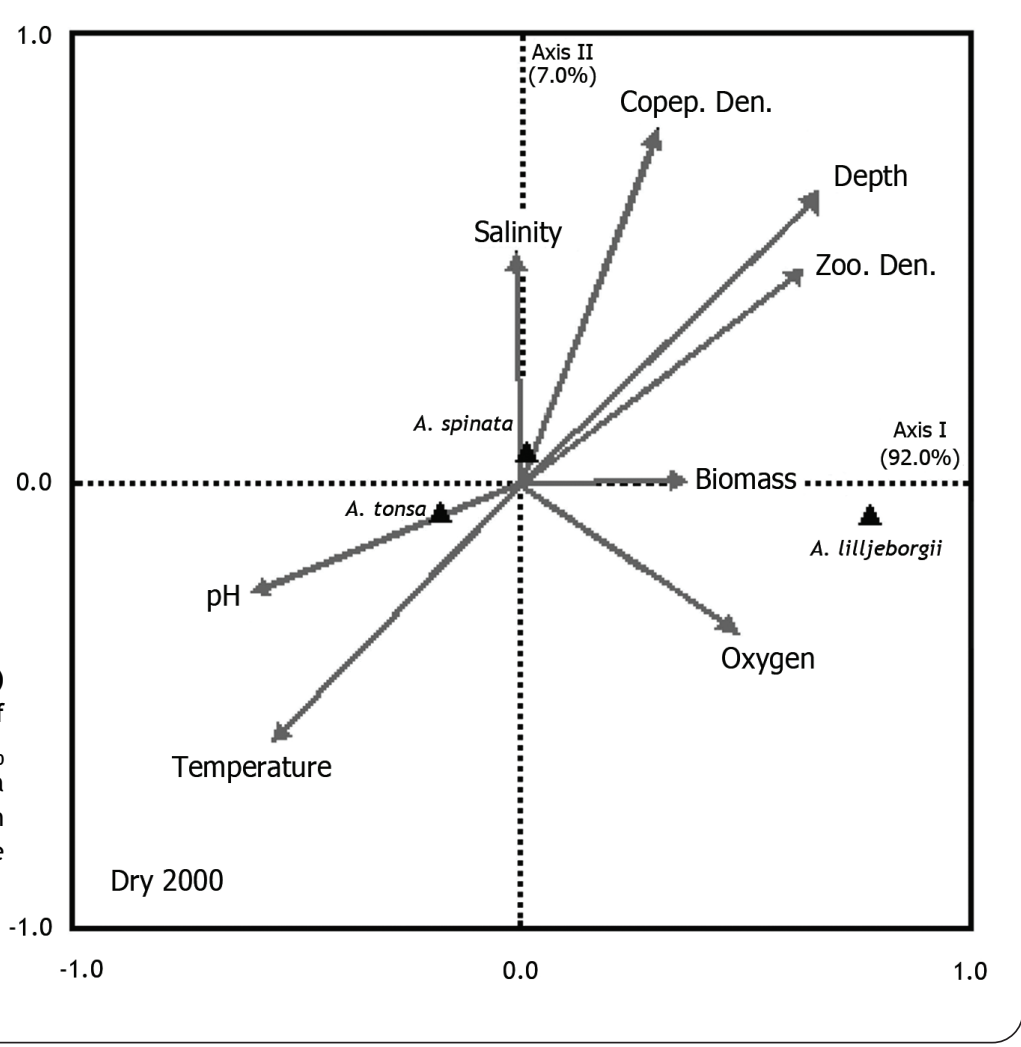

Vol. 46, №3, 2011 


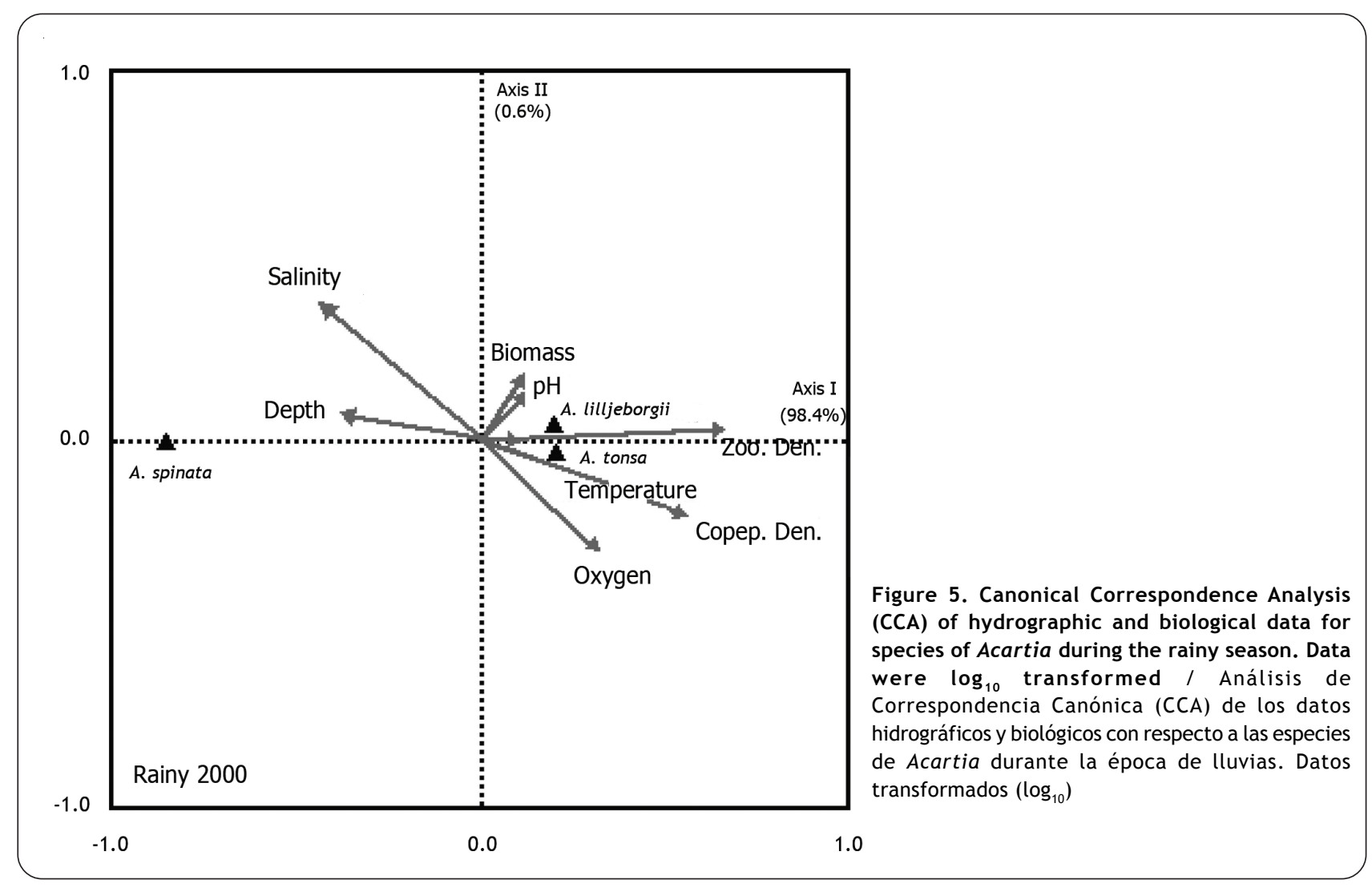

\section{Discussion}

The analysis of the hydrographic data recorded in Chelem revealed a spatial zonation of the system but also a seasonal pattern involving distinctive changes of general conditions during each of the three seasons surveyed. According to the results by Valdés-Lozano (1995) and Herrera-Silveira et al. (1999) in this coastal system, such variations result from the confluence of different factors including the intensity of winds, patterns of advective processes, residence time of water, and intensity of land effluents (springs).

Considering the variability of the biomass average in Chelem $\left(114.7 \pm 92.9 \mathrm{mg} \mathrm{m}^{-3}\right)$, the wet weight zooplankton biomass is within the range reported for other coastal lagoons with similar physiographic features (BatlloriSampedro 1988, Ordóñez-López \& Ornelas-Roa 2003). These values are higher than those recorded from other semi-enclosed coastal systems of the western Caribbean coast such as Chetumal Bay (1-25 $\mathrm{mg} \mathrm{m}^{-3}$ ) (Gasca et al. 1994) but lower than those recorded for systems with an open oceanic front (25-125 $\mathrm{mg} \mathrm{m}^{-3}$ ) (Suárez-Morales \& Gasca 1994). However, according to Escamilla et al. (2001), the high residence time of water in Chelem favors relatively homogeneous local biomass values and thus relatively high food availability for copepod populations.
The three species of Acartia recorded in this system are commonly found in other coastal areas of the Western Tropical Atlantic (Suárez-Morales 1994a, Álvarez-Cadena \& Segura-Puertas 1997, Lopes et al. 1998, Ornelas-Roa \& Ordóñez-López 2000). Their abundance in Chelem is also comparable to that recorded for other coastal water bodies in the region (Suárez-Morales \& Gasca 1996, OrnelasRoa \& Ordóñez-López 2000). The dominance of Acartia populations over other copepods has been commonly reported in reference to coastal lagoons and estuaries (Miller 1983, Suárez-Morales 1994 a, b, Sterza \& LoureiroFernandes 2006); however, in some other tropical estuarine systems Acartia is not dominant (Hwang et al. 2010).

The highest overall abundances of Acartia (nearly $60 \%$ of the total) were recorded at the outer zone of Chelem, related to an average salinity of 30.5 psu and a temperature of $24.8^{\circ} \mathrm{C}$. This pattern agrees with the known affinity of these estuarine-coastal species of Acartia in tropical inshore environments (Lopes et al. 1998, OrnelasRoa \& Ordóñez-López 2000, Suárez-Morales et al. 2009). 
Overall, the presence of abundant populations of Acartia in the same area, suggests both sustained food availability and continuous competition; being a shallow system it is presumed that phytoplankton and small zooplankters are highly available along the water column. Many species of Acartia, including A. tonsa, feed on heterotrophic and autotrophic prey (Rollwagen-Bollens \& Penry 2003). The evaluation of the trophic relations within the system should include an analysis of all the developmental stages of these copepods. The abundances reported here are in reference to adult populations only; future surveys should take into account juvenile (copepodite) numbers in order to determine the seasonal population dynamics of each species in the area (Hoffmeyer et al. 2009).

Acartia lilljeborgii is widely distributed in estuaries with salinities ranging from 20 to $30 \mathrm{psu}$, with no detectable variations in abundance along the gradient (Sterza \& Loureiro-Fernandes 2006). Acartia tonsa can occur in oligohaline systems like the bay of Chetumal (SuárezMorales 1994a) and also in hyper-saline lagoons of the Gulf of Mexico like Laguna Madre and Corpus Christi bay (Britton \& Morton 1989), basically due to a wide tolerance to varying salinities (Cervetto et al. 1999), but it is usually dominant within the innermost reaches of the coastal systems (Sabatini 1989), a pattern observed in Chelem only during the dry season.

Both species of Acartia appear to feed on the same resources when they are present in the same system (Kennish 1986), but they can coexist because of the space and time segregation effected by the local restrictions imposed by the small scale changes of saline conditions and tidal patterns (Suárez-Morales 1994a, Escamilla et al. 2001). So, in order to coexist in the same system with a similar spatial distribution for long periods, a shift in the seasonal succession would then become a strategy to avoid continuous competition. According to our results, such a pattern could be occurring in Chelem, where the highest overall abundances of $A$. tonsa occurred in the outer zone and during the rainy season, whereas $A$. lilljeborgii reached its maximum abundance in the same area, but during the dry season. The distribution of $A$. tonsa and $A$. lilljeborgii within the inner or outer zones (Table 3), was different during seasons, i.e., A. tonsa was more abundant in the outer zone while A. lilljeborgii was abundant in the inner zone during nortes, however, the abundances of these two copepods were opposite during the dry season. During the rainy season, both species were more abundant in the outer zone, probably avoiding lower salinity conditions at the inner zone. Seasonal conditions modify the structure and distribution of local populations of Acartia. This is also supported by the results of the two-way ANOVA and the CCA, as discussed below. In this regard, Miller (1983) noted the existence of a temporal and spatial succession between species of Acartia in estuaries at higher latitudes, where A. clausi Giesbrecht, 1892 often replaces $A$. tonsa. Similar results were previously reported by Jeffries (1962). Similarly, Sullivan et al. (2007) described the succession of $A$. tonsa and $A$. hudsonica in the North Atlantic Ocean, but in this case, this process is clearly related to temperature; the former is replaced during the winter. Suárez-Morales (1994b) mentioned that in warm coastal waters it is likely that $A$. lilljeborgii replaces $A$. tonsa, which is dominant in coastal lagoons of the Gulf of Mexico and the Mexican Pacific.

On the other hand, A. spinata, with a well-known marine affinity (Suárez-Morales et al. 2009), is among the predominant species in an adjacent reef lagoon (SuárezMorales \& Gasca 2000). However, it was the least abundant species of Acartia in Chelem. Its affinity for more saline waters would explain its greater abundance in the deeper area with the strongest marine influence in Chelem (outer zone) during at least two seasons (nortes and dry). In relatively stable estuarine systems with persisting zonal conditions, up to four species of Acartia have been known to coexist (Alcaraz 1983). The relatively high residence time of water in Chelem (Escamilla et al. 2001) together with the salinity gradients and also other factors (as suggested by the CCA) appear to be relevant in allowing the coexistence of three congeneric species of copepods.

Aside from temperature and salinity, there are other unexplored environmental factors that might be important to understand these patterns. There are no previous data about the tolerance of dominant species of Acartia to changes in $\mathrm{pH}$; our results of the overall abundance of Acartia in Chelem suggest that they tend to become less abundant in waters with $\mathrm{pH}$ values greater than 8.2 (inner zone) during the three seasonal periods (see Tables 1, 3). However, the CCA indicated that $A$. tonsa and $A$. lilljeborgii appear to be differently correlated with $\mathrm{pH}$ in the nortes and dry seasons (Figs. 3, 4). During the rainy season, when the $\mathrm{pH}$ is more homogeneous, both species have nearly the same correlation with this factor. In a temperate coastal system of South America, differential responses to certain parameters have been described as relevant in allowing the coexistence between two species 
with similar characteristics. The developmental stages of A. tonsa were most positively correlated with temperature and photoperiod whereas the estuarine Eurytemora americana, showed positive correlations with chlorophyll$a$ and salinity (Hoffmeyer et al. 2009). Hence, the gradients of more than one environmental factor provide a niche separation facilitating the coexistence of two competitive copepods. The tidal pattern could be yet another additional factor contributing in shaping the abundance of some species in Chelem, as suggested by Escamilla et al. (2001) from data obtained during nortes, but the results of Ali et al. (2011) indicated that copepod abundance could be related to other parameters rather than tides.

The different seasonal configurations of the CCA (Figs. 3-5) suggest that there are detectable variations in the local community and also in regards to the effects of the variability of the parameters measured on the distribution and abundance of the species of Acartia. During nortes, when $A$. tonsa was more than 2.5 times more abundant in the outer zone than in the inner sector, its distribution coincided with that of $A$. spinata, clearly related to deeper, more saline waters. In the same season, A. lilljeborgii was correlated with warmer waters, high $\mathrm{pH}$ and oxygen values, that were also kept during the other two seasons. During the dry season the community of Acartia changed; A. lilljeborgii had the highest overall density, which explains its high correlation with the biomass; its abundance tended to be correlated with lower $\mathrm{pH}$ values (Fig. 4). During this season $A$. tonsa was more abundant within the inner zone of Chelem. This is in contrast to $A$. lilljeborgii, which was clearly related to high $\mathrm{pH}$ values. The undefined correlations of $A$. spinata in this season are probably obscured by its very low abundance. In the rainy season the $\mathrm{pH}$ values were more homogeneous and thus both $A$. tonsa and A. lilljeborgii were correlated with this parameter. Both species were also found in relation to high values of temperature, zooplankton density, and dissolved oxygen, whereas $A$. spinata was related to the deeper and more saline sites, as observed during nortes.

Conservation strategies are based on a previous knowledge of the communities; these kind of surveys allow for the detection of non-indigenous planktonic species invading these tropical coastal environments and impacting the ecosystems. Through a monitoring program, these measurements will also help in revealing changes to the structural and functional parameters of the local plankton communities derived from different kinds of alterations. At larger scales, long term changes regarding seasonality of succession for species of Acartia in a coastal system have been studied in relation to global warming (Sullivan et al. 2007); hence, the interannual variability of these patterns should be monitored for this and other coastal systems of the region. Variations of salinity, temperature, and biomass were not the only factors that determined the local distribution patterns of Acartia. It is likely that biological factors such as reproductive cycles, competition and predation have an important role the variation of the abundance of copepod populations in coastal systems (Costello et al. 2006).

\section{ACKNOWLedgments}

The authors give thanks for all the support received from different colleagues and students in the field and laboratory. Positive and relevant comments received from two anonymous referees are deeply appreciated.

\section{LITERATURE CITED}

Alcaraz A. 1983. Coexistence and segregation of congeneric pelagic copepods: spatial distribution of the Acartia complex in the ría of Vigo (NW of Spain). Journal of Plankton Research 5: 891-900.

Ali M, F Al-Yamani \& I Polikarpov. 2011. The effect of tidal cycles on the community structure of plankton (with emphasis on copepods) at AFMED Marina in winter (a preliminary study). Crustaceana 84: 601-621.

Álvarez-Cadena JN \& L Segura-Puertas. 1997. Zooplankton variability and copepod species assemblages from a tropical coastal lagoon. Gulf Research Reports 9: 345-355.

Álvarez-Cadena JN, U Ordóñez-López, D Valdés-Lozano, AR Almaral \& A Uicab-Sabido. 2007. Estudio anual del zooplancton: composición, abundancia, biomasa e hidrología del norte de Quintana Roo, mar Caribe de México. Revista Mexicana de Biodiversidad 78: 421-430.

Batllori-Sampedro E. 1988. Producción secundaria en el estero de Celestún. Master of Science Thesis, Departamento de Recursos del Mar, CINVESTAV-IPN, Unidad Mérida, Mexico, 140 pp.

Beers JR. 1981. Determinación de la biomasa del zooplancton. In: Boltovskoy D (ed). Atlas del zooplancton del Atlántico Sudoccidental y métodos de trabajo con el zooplancton marino, pp. 133-141. Instituto National de Investigación y Desarrollo Pesquero, INIDEP, Mar del Plata.

Braak CJF Ter \& PFM Verdonschot. 1995. Canonical correspondence analysis and related multivariate methods in aquatic ecology. Aquatic Sciences 57(3): 255-288.

Britton JC \& B Morton. 1989. Shore ecology of the Gulf of Mexico, 387 pp. University of Texas Press, Austin. 
Campos-Hernández A \& E Suárez-Morales. 1994 Copépodos pelágicos del Golfo de México y Mar Caribe. Biología y sistemática, 359 pp. CONACYT/CIQRO, México.

Cervetto G, R Gaudy \& M Pagano. 1999. Influence of salinity on the distribution of Acartia tonsa (Copepoda, Calanoida). Journal of Experimental Marine Biology and Ecology 239: 33-45.

Costello JH, BK Sullivan \& DJ Gifford. 2006. A physicalbiological interaction underlying variable phonological responses to climate change by coastal zooplankton. Journal of Plankton Research 28: 1099-1105.

Elliott M \& DS McLusky. 2002. The need for definition in understanding estuaries. Estuarine, Coastal \& Shelf Science 55: $815-827$

Escamilla JB \& E Suárez-Morales. 1999. Lista preliminar de copépodos (Crustacea) de la laguna de Chelem y aguas marinas adyacentes, Yucatán, México. Invierno de 1998/ 99. Revista de la División de Estudios de Posgrado e Investigación, Instituto Tecnológico de Mérida 37: 32-38.

Escamilla JB, E Suárez-Morales \& R Gasca. 2001. Distribución del zooplancton durante flujos de marea opuestos en el complejo lagunar de Chelem, Yucatán México. Revista de Biología Tropical 49: 47-51

Gasca R, E Suárez-Morales \& L Vásquez-Yeomans. 1994. Estudio comparativo del zooplancton (biomasa y composición) en dos bahías del Mar Caribe mexicano. Revista de Biología Tropical 42: 595-604.

Harris RP, PH Wiebe, J Lenz, HR Skjoldal \& M Huntley. 2000. Zooplankton methodology manual, 684 pp. Academic Press, London.

Herrera-Silveira J. 2006. Lagunas costeras de Yucatán (SE, México): investigación, diagnóstico y manejo. Ecotrópicos 19: 94-108.

Herrera-Silveira J, J Ramírez-Ramírez \& A Saldívar. 1999. Overview and characterization of the hydrology and primary producer communities of selected costal lagoons of Yucatan, Mexico. Aquatic Ecosystem Health and Management 1:353-372.

Hoffmeyer M, AA Berasategui, D Beigt \& MC Piccolo. 2009. Environmental regulation of the estuarine copepods Acartia tonsa and Eurytemora americana during coexistence period. Journal of the Marine Biological Association of the United Kingdom 89: 355-361.

Hwang JS, S Souissi, LC Tseng, L Seuront, F Schmitt \& LS Fang. 2006. A 5-year study of the influence of the northeast and southwest monsoons on copepod assemblages in the boundary coastal waters between the East China Sea and the Taiwan Strait. Journal of Plankton Research 28: 943-958.
Hwang JS, R Kumar, CW Hsieh, AY Kuo, S Souissi, MH Hsu, JT Wu, WC Liu, CF Wang \& QC Chen. 2010. Patterns of zooplankton distribution along the marine, estuarine, and riverine portions of the Danshuei Ecosystem in Northern Taiwan Zoological Studies 49(3): 335-352.

Jeffries HP. 1962. Succession of two Acartia species in estuaries. Limnology \& Oceanography 7: 354-364.

Kennish MJ. 1986. Ecology of estuaries: biological aspects, 390 pp. CRC Press, Boca Raton.

Lopes RM, R do Vale \& FP Brandini. 1998. Composição, abundância e distribuição espacial do zooplâncton no complexo estuarino de Paranaguá durante o inverno de 1993 e o verão de 1994. Revista Brasileira de Oceanografía 46:195-211.

Malone TC, DJ Conley, TR Fisher, PM Gilbert \& LW Harding. 1996. Scales of nutrient-limited phytoplankton productivity in Chesapeake Bay. Estuaries 19: 371-385.

Miller CB. 1983. The zooplankton of estuaries. In: Ketchum $\mathrm{BH}$ (ed). Estuaries and enclosed seas. Ecosystems of the world 26: 103-149. Elsevier Scientific Publishing, New York.

Ordóñez-López U \& M Ornelas-Roa. 2003. Variación de la comunidad de copépodos pláncticos en el gradiente estuarino-costero de Celestún, Yucatán, México. Hidrobiológica 13: 231-238.

Ornelas-Roa M \& U Ordóñez-López. 2000. Variaciones espacio-temporales de Acartia tonsa Dana, Acartia lilljeborgii Giesbrecht y Pseudodiaptomus cokeri González y Bowman y su relación con la hidrología en el estero de Celestún, Yucatán. Scientia Naturae 3: 5-17.

Rollwagen-Bollens GC \& DL Penry. 2003. Feeding dynamics of Acartia spp. Copepods in a large, temperate estuary (San Francisco Bay, CA). Marine Ecology Progress Series: 257: 139-158.

Sabatini MA. 1989. Ciclo anual del copépodo Acartia tonsa Dana, 1849 en la zona interna de la Bahía Blanca (Provincia de Buenos Aires, Argentina). Scientia Marina 53: 847-856.

Sterza JM \& L Loureiro-Fernandes. 2006. Zooplankton community of the Vitória bay estuarine system (Southeastern Brazil) characterization during a three-year study. Brazilian Journal of Oceanography 54: 95-105.

Suárez-Morales E. 1994a. Copépodos pláncticos de la Bahía de Chetumal, México (1990-1991). Caribbean Journal of Science 30: 181-188.

Suárez-Morales E. 1994b. Comunidades zooplanctónicas de las lagunas costeras. In: De la Lanza-Espino G \& C CáceresMartínez (eds). Lagunas costeras y el litoral mexicano, pp. 247-268. Universidad Autónoma de Baja California Sur, La Paz. 
Suárez-Morales E \& R Gasca. 1994. Zooplankton biomass fluctuations in a Mexican Caribbean Bay (Bahía de la Ascensión) during a year cycle. Caribbean Journal of Science 38: 116-123.

Suárez-Morales E \& R Gasca. 1996. Planktonic copepods of bahía de la Ascensión, Caribbean coast of México: a seasonal survey. Crustaceana 69: 161-174.

Suárez-Morales E \& R Gasca. 2000. The planktonic copepod community at Mahahual reef, Western Caribbean. Bulletin of Marine Science 66: 255-267.

Suárez-Morales E, JW Fleeger \& PA Montagna. 2009. Freeliving Copepoda (Crustacea) of the Gulf of Mexico. In: Felder DL \& DK Camp (eds). Gulf of Mexico. Origin, Waters, and Biota 1: 841-869. Texas A\&M University, Texas.

Sullivan BK, JH Costello \& D Van Keuren. 2007. Seasonality of the copepods Acartia hudsonica and Acartia tonsa in Narragansett Bay, RI, USA during a period of climate change. Estuarine, Coastal and Shelf Science 73: 259-267.
Valdés-Lozano D. 1995. Procesos que regulan el nitrógeno inorgánico y variaciones estacionales de la hidrología en la laguna de Chelem, Yucatán. Doctoral Dissertation, Departamento de Recursos del Mar, CINVESTAV-IPN, Mérida, Mexico, 198 pp.

Waniek JJ. 2003. The role of physical forcing in initiation of spring blooms in the northeast Atlantic. Journal of Marine Systems 39: 57-82.

Zar JH. 1988. Biostatistical analysis, 718 pp. Prentice Hall, Englewood Cliffs.

Zizumbo D. 1989. El deterioro del sistema ecológico de Ciénega de Progreso, 89 pp. Secretaría de Ecología, Gobierno del Estado de Yucatán, México.

Received 2 April 2011 and accepted 3 November 2011 